\title{
Discerning the Antecedents of Land Tenure and Military Nobility in Feudal Japan since the $7^{\text {th }}$ Century
}

\author{
Agney G K \\ Mar Thoma College, M G University, Thiruvalla, Kerala, India \\ Email: gkagni@gmail.com
}

Keywords: SHO, SHIKI, MILITARY NOBILITY, TAIKA REFORMS, SHOGUN.

\begin{abstract}
This paper illustrates the various phases in the development of feudal tendencies in Japan, with special reference to the disintegrating centralised administration, the tax immune sho, the transferable shiki and the final over powering of the civil nobility by the military nobility, since the Yomato period to the $13^{\text {th }}$ century. The paper particularly throws light on how misguided and ill calculated politico-economic reforms, like the Taika reforms of the $7^{\text {th }}$ century, were instrumental in overthrowing the existing nature of land relations and provincial administrative apparatus and give way to the accumulation of landed property by both the nobles and the Buddhist church and to a powerful military nobility with strong regional roots.
\end{abstract}

\section{Introduction}

The beginning of the $10^{\text {th }}$ century, in Europe, witnessed the commencement of a social formation which was fundamentally different from the Greco- Roman antiquity. This feudal mode of production replaced the slave social formation, and led to the synthesis of two disintegrating societies, the Roman and the Germanic. The collapse of the Roman Empire impelled the Germanic chiefs to usurp secular function of the state. The exigencies that existed during the $9^{\text {th }}$ century allowed these lords to regularise their position by developing a hierarchical structure, where by the big lords derived their investiture from the King and in turn sanctioned the authority of the lesser lords, below them, leading to the 'parcellization of sovereignty' in medieval Europe. The development of fief and military system, two essential components of feudalism, were the direct result of the attempts of the Carolingians to organise administration and recruit troops on a regular basis, at a time when dissolution of the Roman army and the disintegration of the tribal military organisation of the Germanic tribes threatened the maintenance of class differentiation arduous without sufficient armed force.

'The question whether the idea of feudalism can be applied to Japan or any other non-Western Europeans societies has exercised the minds of the scholars since the time of Voltaire and 
Montesquieu'. The question still remains unsettled at large. But this author would not delve in to the aforesaid topic, but acknowledges that Japan which lies half way across the world from Western Europe developed 'peculiarly definite and exhaustive social adjustments' that can be adjudged as Feudal, and would concentrate chiefly on the 'origin of fief and military nobility' in feudal Japan. Though feudalism, in its appropriateness, began in Japan no sooner than the second half of the tenth century (a time bracket of 1185-1868 A.D is provided by historians like Milton W Meyer), this study would, as the title suggests, delve into the antecedents of feudalism which can be traced back to the $7^{\text {th }}$ century. The paper will consider the period from the late $7^{\text {th }}$ century coinciding with the expiration of Yomato period, till coming into prevalence of fief in the $13^{\text {th }}$ century, as the span of reference for the study.

\section{The Antecedents of Feudalism}

The initial impetus for the development of feudalism in Japan came from mistargeted and less calculated attempts at regularising the reallotment of land which back fired like most other reforms since the $7^{\text {th }}$ century. By the end of the $7^{\text {th }}$ century the rising power of the patriarchs (that could rival the imperial authority), along with the increasing tendency towards decentralisation and the threat of Chinese invasion necessitate the great reforms of the $7^{\text {th }}$ century, popularly known as the Taika reforms, which accomplished many changes in property relations, but not the intended ones. In consonance with the Taika reforms, all the private land that existed hitherto were abolished and all earth came to be centralized in the name of the Emperor, who apportioned it on the basis of household in a proportionate field system. The Taika reforms also implemented three kinds of taxes- the grain tax, the tax on products other than cereals and one of labour (corvee). By the early $8^{\text {th }}$ century the Japanese Monarch moved out of his traditional ground- the Yamato plain, to the north, the Nara region, a move supported by the powerful nobles in an attempt to increase their influence on the imperial power. The Nara politics revolved around the concept of an all-powerful monarch. By the end of the $8^{\text {th }}$ century, power began to slither from the hands of the monarch. An era ushered, where the hitherto all-powerful Monarch was considered only as a figure head, while the regent ruled from behind the throne. To this precarious position of the monarch was added the practice of royal abdication, in the $8^{\text {th }}$ century, which further weakened the crown. This initiated an era where the powerful nobles pressurized the crown to abdicate in favour of a weak successor. The height of this vice can be gauged from the fact that three ex monarchs lived at the same time. The later Heian period (987-1185) laid the bedrock for feudalism in Japan. The Japanese were prudent in adopting any Chinese practice of that time but meritocracy. The Japanese nobility and bureaucracy still were based on birth thus buttressing family or clan feeling. Each clan was desperate to control the lion share of sovereign functions. The contrite condition of the monarch can be presumed from the tardiness in promulgating the Taiho code of the year 702 and the Yoro code of 718, which dealt with penal laws and administrative practices, not until the coming of Yoritamo to power.

New nobility in Japan was conceived as a result of the reforms of the $7^{\text {th }}$ century. This new nobility was entrusted with the responsibility of provincial and local administration. The old nobility was still stationed at the imperial court and received a grant of 30 acres of land as salary and also for maintaining their office. But they were so engrossed in the power struggle at the imperial court that they never felt it mandatory to monitor the affairs of their holdings, and marooned it to the subordinate district officers, thus promoting absentee landlordism. This system worked well until the Emperor was able to affect periodic transfer of the provincial and district officers. But the system soon collapsed when the new nobility became powerful enough to defy the orders of the emperor, and hold the office by heredity. They cemented their position subsequent by 
acquiring military characteristics. The military attribute of the new nobility and feudal tendencies moved hand in glove, aiding each other. But this should not be equated with the demise of the civil nobility. The civil nobility could not be eclipsed by the military nobility till the $12^{\text {th }}$ century. By the later Heian period the Fujiwara nobles (the powerful clan of the civil nobility) was able to appoint themselves as the regent of the incumbent Emperor. The rise in strength of the Fujiwara can be seen from the fact that all the successive emperors had Fujiwara mothers, thus by perpetuating regency. The forced abdication reached a new level whereby no adult Emperor was allowed to sit on the throne, and was forced to abdicate once he crossed his childhood. The epitome of the Fujiwara strength can be witnessed under the regency of Fujiwara no Michinaga (995-1027). Further many of the Fujiwara nobles accepted the title of Kanpaku or civil dictators. It was only after the weakening of the Fujiwara nobles, disintegration began after the reign of Fujiwara no Michinaga, that the Military nobility could hold their sway.

The supporting or taxable class constituted the bulk of the citizen. As in any feudal societies, they held the lowest rung in the political and social structure. The freemen received one half of an acre of rice field as a result of the land distribution policies during the Taika period. Though the Taika reforms also spoke of reallotment of land every few years to keep it in the hands of the free farmers, the powerful nobles and the Buddhist Church was adamant on precluding any attempt towards the same by accumulating large land holdings. Thus these elements led to the drubbing of the purpose of this scheme. The system failed to comprehend all the land and the people that existed. Another stag in the system was the decision to allow the holder of the land to transfer the title, by sale or mortgage, of the holding. This authored an imbalance in the system by the beginning of the $8^{\text {th }}$ century, where by the temples and nobles began to rack up more earth, and the land came to be neither equal nor realloted. Though the new nobility was conceived on a new basis, it was new only in nomenclature. In practice it resembled the old patriarchal nobility, desperate in coveting private possession of land and men.

The linear consequence of the rupture of reforms of the $7^{\text {th }}$ century was the bolstering of feudal tendencies and the proliferation of private landed estates (Sho or Shoen) in Japan. Sho was fundamentally a rice cultivating area under private ownership and management. It was the result of the accumulation of land, beginning in the $7^{\text {th }}$ century, contravening the imperial decrees. Private ownership provided tremendous incentives for various groups to enlarge their estates as much as possible, leading to the emergence of new centres of wealth and power. Generally there were two different kinds of sho, the one owned by aristocrats sent out from political centre and the other by farmers, who had built up sizeable holdings. The latter was constantly afraid that they may lose their tax free status to a government that was desperate for revenue. In a period where minted coins were scare and had to be imported from China, land was the basic unit of wealth and power. Land was scarce in Japan. The population of the time was increasing and there was a consequent need to bring more land under cultivation. To encourage this government allowed newly cultivated land to be tax free for three generations. Because of the already heavy demand on peasant, those best able to take advantage of this new policy were farmers who already had substantial land holdings, aristocrats and bureaucrats governing the countryside and temples. They often used slave labour or land less peasants for work on the new fields. Many of the peasants fled from villages when the demand on them became too much, and negotiated with those opening up new areas of work in the fields while avoiding corvee labour and military service. The nobles were unsuccessful in carving large holdings in the $8^{\text {th }}$ century, but the temples. The Sho is often pronounced, in $8^{\text {th }}$ century, in relation with the temples. The accomplishment of the temple was not only due to its 'illegal' aggrandizement but also due to the imperial policy of promoting donation of land, to ward off evil, 
epidemics and calamities, by private individuals to the temples. As the temple land was tax free, more and more land came to be added to this bracket. The church also began to accumulate land through purchase, mortgage and gift, which was conceded by the reforms of the $7^{\text {th }}$ century. By the $9^{\text {th }}$ century, the land grants to the Buddhist Church began to grow exponentially. To this distress was added the convention of reservation and partial cultivation of extensive tracts set apart for free disposal by the Emperor. The imperial lands thus created by the setting apart of land were granted by the Emperor to members of his house and other high ranked nobles. Like the temple lands, this imperial land was also tax immune. This promoted a convention by which the grantee or the one who received the land as grant from the original grantee, claiming all his landed possessions as tax immune, because of the existence of imperial land, as a portion, among his other holdings. Thus most of the land came to be deemed as tax free land and only a portion, the land left with the ordinary peasant, was deemed taxable, putting heavy tax burden on these peasants.

Till the $8^{\text {th }}$ century the growth of sho was restricted only to the rice cultivating lands, most of which were registered. This facilitated the emperor to keep an account of the amount of land with the citizenry and with the nobles and the temples. But by the $8^{\text {th }}$ century, the Sho represented a vertical trajectory, by capturing meadows and woodlands in its respective vicinity. This led to a complete bewilderment, as no records were accurate on the amount of land converted as Sho. The emperor still had the heart for reforms, in which he decreed that the peasant will have the ownership of the analogues land he brings under cultivation. Though the policy was destined to benefit the citizenry, it backfired, and played out in favour of the nobles, with the effect of rampant multiplication of Sho and easy transfer of land. To all these precariousness was added, in the $9^{\text {th }}$ century, the sensuality of commendation of land to claim tax immunity. The commendation of sho only reduplicated in the subsequent century, though it was still deemed illegal. Emperor Go-Sanjo, in 1069, resolved to bridle this exponential growth by rescinding all sho created after 1045 AD and all before, which lacked corresponding charter. But as fate would have it, abolition of illegal sho led to the increase in the number of 'legal' sho. The managers and holders of the illegal sho made better of the rampant corruption and mismanagement of affairs in the provinces, attaining legality and perpetuity to these holdings. The charter thus received, defined its boundaries, exempted them from taxation and prevented the provincial officials from invading them. Thus by the $12^{\text {th }}$ century, the imperial land, which was the legal sho of the pre 1069 reform, and the granted land, the illegal sho of the pre 1069 reform period, came to be considered as tantamount and legal. By the $12^{\text {th }}$ century, half of all the agricultural land had been transformed as private sho, and the other half was left with the Monarch as the imperial land. This new development reinforced the decentralisation trends already in operation. The Japanese administrative mechanism was thus reconfigured making the provincial leaders comparatively powerful. The fear of the farmers with large holdings, of the loss of their tax free status, as the government was looking forward to all avenues to increase its tax base forced them to give up the formal title in favour of these provincial power centres.

The extension of immunity to the sho progressed side by side with the private conveyance of the real rights relative to the sho, called Shiki. The elementary form of shiki could have accrued due to the use of land or the collection of dues. But it diversified in the ensuing aeon. This diversification was concurrent with the transferring of these rights from one person to another. Feudalism in Japan not only sworn in the parcellization of authority but also ownership - both nominal and real, over land. Once the right was taken out from the holder it was impossible to curb its further division. Though both surrender (commendation) and granting (benefice) came to mean the transfer of rights, both were different in their institutional origin. Though, the original holder of a commended land, renunciated ownership, functioned henceforth as the steward of the sho, in verisimilitude he 
retained its possession and delivered only a part of the dues on the land. The Japanese Commendation was ideologically different from its western European counterparts in two counts. Primarily, the Commendor, or the one who capitulated the land, had the power to revoke the agreement, given the fact that the commendee, or the higher lord tried to tamper with the management of the estate. Secondly, he was empowered to transfer the reserved rights, the rights that a Commendor held even after the commendation of the land, to another commendee. This particular attribute created a hierarchy of ownership in the land, till it reached the highest lord, just below the Emperor. But still the real right of the land was vested with the Commendor, who could have inhibited the growth of feudalism in Japan, had not the military nobility came in to being, which resulted in the creation fief. In the later period along with tax immunity, Judicial and administrative immunity also came to be bestowed on the commended land.

The Japanese warrior was also the harvest of failed reforms of the $7^{\text {th }}$ century, which eventuated tensions in the society. The origin of the warriors in Japan was not the result of a solo and plain process, but of three independent processes. When Emperor Kanmu (781-806) came to power, he shifted his capital to Kyoto and a metropolitan police was conceived and posted both at the capital and the provinces to keep a close eye on the developments. The situation was aggravated by the abolition of military conscription in 792. The abolition led to the pre mature retirement of guards who functioned as the protectors of aristocratic families and as police. They having found it difficult to pursue other avenues, evolved in to warriors. The stalwart youths who were entrusted by the centre to prevent the outlying areas from the barbarians also became warriors when the central authority eroded and regional power centres evolved. As the nobles and temples began to collect land and claim tax free status, the state turned towards the peasants outside the sho to assuage its economic demands. The escalating expenditure of the $8^{\text {th }}$ century further put the economic condition of peasants in tribulation, compelling them to abandon their land and become outlaws. This led to the further exacerbation of the tension between the various classes and deepened the ruckus in the society. The foot soldiers and the police maintained by the Emperor were incompetent in the face of this new challenge. This forced the owners or managers of sho in the provinces to recruit private soldiers, to defend their holdings, though the practice was forbidden from the onset. As the lawlessness began to intensify, the lesser nobles, found it better to commentate their land to a higher lord, who could insure conservation of these holdings. The protection thus granted emboldened these stewards to spurn the provincial officers with impunity. Private militia, of a family or clan genesis began to be mobilised by provincial officers, who developed local interest and flouted the periodic transfer. Thus the clash of the old and new landed magnets among themselves and against one another, led to the origin of private and illegal warriors. Some families were particularly interested in augmenting their military prowess and dreamed to become the regional powers overtime. These groups taken together formed the basis of the early samurais. The higher nobles, who resided in the court also found it pertinent to confederate with local chieftains, who maintained armed men. This led to the rise of benefice holdings by the early $10^{\text {th }}$ century.

The parallel extension of tax immunity and sho forced more and more warriors to be included in the sho. The warriors stationed in a sho also impeded the fickle minded Commendor from terminating the agreement with the commendee at will and entering into a new contractual relationship with a new noble or a temple. But till the $10^{\text {th }}$ century the civil nobility retained the sho and appointed stewards for their protection. The military nobility, which waxed in influence by the middle of $11^{\text {th }}$ century, were the product of existing political and economic acuteness which forced many of the members of the royal families to move out of the imperial court and accept inferior ranks in the provinces. This new nobility soon took control of the sho which were owned by the 
absentee landlords. Though the power of the military nobility was steadily increasing as a result of the alliances forged with the local warriors, they were in no manner capable of challenging the civil nobility.

The restlessness that continued in the society forced the more active elements to unmake and remake alliances which suited their interest. Thus $11^{\text {th }}$ century saw increase in commendation of land on a large scale to the military nobility, where the nominal rights were earlier enjoyed by the civil nobility. This mutual agreement succoured both the Commendor, who became 'the man' of a power man, and the military nobility, to whom the upsurge in influence meant stability in existence. By the late $11^{\text {th }}$ century the power of the Fujiwara nobles began to wane. The intermittent warfare engendered a feeling of personal loyalty and bounded up the interest of the military nobility against the civil nobility. 'The private organisation of men and land gained, in hierarchical unity under the impetus of the revived spirit of clannism and also in complex division of families and their shiki in land'. The feudal tendencies accompanying the land were getting stronger by the $12^{\text {th }}$ century, a fact attested by the hereditary attaching of tillers to the land. The manager of an estate, who himself was a noble, usually found benefice in an extensive sho comprising numerous tracts, compelling. His prestige was further higher if he was a hereditary higher official of a province. Eventually the central government came to depend on the military power of these families, partly to control the unruly elements in the country side and also to settle disputes over succession with in the imperial family. The direct intervention of the military nobility in setting succession disputes came in 1156 and since then they came to play a pivotal role in governing Japan.

The feudal trends in Japan were amplified with the appointment of Yoritamo as the power behind the throne. He systematised land distribution by appointing stewards or overseers and constables responsible directly to him and also by taking into his hands the appointment of estates managers, which was a prerogative of the individual lords. This made him the head of Stewards, Daimyo (greater lords of the later feudal period and in the Tokugawa era, which evolved from the Constables) and provincial Governors. He then went on to make these officers hereditary. His government was known as the bakufu, meaning tent headquarters, reflecting its military origins. The feudal tendencies reached its epitome after the appointment of Yoritamo as Shogun. As financial resources was necessary to carry forward such a military enterprise he cancelled all the charters that granted tax immunity to holdings, thus solving the tensions that existed in the society and also the financial crisis of both the Empire and the Emperor. He was successful in transforming the Shogunate from a simple military organ into an effective military agency of indirect rule.

But till the $13^{\text {th }}$ century, the main element of a feudal society was still wanting in Japan, the animation of fief. As discussed earlier the benefice and commendation had a different institutional origin. So that if the holder of a commended land passed away the land was accrued to the holder's successors, who may commentate the land to another noble. In case of benefice, after the demise of a servant, the noble can allot it to another servant. But once the military nobility came to be established, the communities on the holding began to be organised by the bonds of shiki and feudal rights and privileges rather than blood relations. Thus by the $13^{\text {th }}$ century, the nominal ownership of a land could no longer be conveyed but only be divided and bequeathed among the children of the vassal and was also capable of subinfeudation. This trend of assimilating the two tenures and bringing about a gradual evolution of the fief as in Europe came to be much established by the $15^{\text {th }}$ and $16^{\text {th }}$ century. 


\section{References}

[1]Andresson, Curtis.(2000) A short history of Japan- from Samurai to Sony, Alexander street, Allen and Unwin, 1-78 [2]Meyer, Milton W.(2009) Japan- A Concise History, Lanham, Rowman and Littlefield publishers,31-85

[3]Asakawa, Kan'ichi.(1914) The Origin of Feudal land tenure in Japan, The American Historical Review, 20,1-26

[4]Farooqui. Amar.(2008) Early Social Formations, Manak Publications,367-473

[5]Anderson, Perry.(2000) Passage from Antiquity to Feudalism, Verso 107-197

[6]Hall, John Whitney.(1962) Feudalism in Japan- A Reassessment, Cambridge University Press,5,1-47

[7]Hall, John Whitney.(2006) The Cambridge history of Japan, Cambridge University press, 46-123

[8]Tsuchik, Tamio.(2001) The new generation of Japanese Swordsmiths, Kodansha International, 